\title{
PREDICTIVE POTENTIAL OF MACROPHAGE POPULATION PHENOTYPING IN MALIGNIZATION OF H. PYLORI-ASSOCIATED CHRONIC GASTRITIS
}

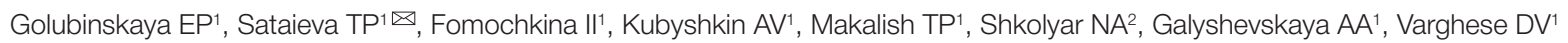

${ }^{1}$ V.I. Vernadsky Crimea Federal University, Simferopol, Russia

2 Sechenov University, Moscow, Russia

Tumor-associated macrophages are able to regulate the tumor cell proliferation and to affect the tumor cell dissemination. The study was aimed to assess the predictive potential of the macrophage population immunohistochemical phenotyping in early malignization of $\mathrm{H}$. pylori-associated chronic gastritis. Gastic biopsy samples of male and female patients aged $48 \pm 7.2$ infected with Helicobacter pylori were used as the research material. The patients were divided into three groups: non-atrophic chronic gastritis (NACG, $n=10$ ), atrophic chronic gastritis (ACG, $n=10$ ), G1/G2 gastric adenocarcinoma (GAC, $n=10$ ). The macrophage population was visualized using the CD68 pan-macrophage marker and the type 2 monocyte/macrophage marker CD163. Intensity of neoangiogenesis was defined using the CD31 endothelial marker by assessing the total cross sectional area of blood vessels. It was found that chronic gastritis was accompanied by the dynamic increase in the size of the general macrophage population with the progression of atrophic and metaplastic processes. According to immunohistochemical study of biopsies obtained from patients with NCG, the CD163: CD68 ratio was $0.67 \pm 0.02$, and the total cross sectional area of blood vessels was $3590.92 \pm 356.27 \mu \mathrm{m}^{2}$. Atrophic gastritis and adenocarcinoma were characterized by vector redistribution of monocytes/macrophages into the $2^{\text {nd }}$ functional phenotype. The CD163 : CD68 expression index in the group with ACG was $0.81 \pm 0.04$, and in the group with GAC it was $0.88 \pm 0.03$. Microvascular area was significantly increased in the groups with $A C G$ and GAC, which reflected tumor neoangiogenesis intensification under the influence of M2 monocytes/macrophages. The increased expression of CD163 can serve as a predictor of chronic gastritis malignization together with evaluation of the glandular epithelium atrophy and metaplasia degree.

Keywords: gastric cancer, gastritis, adenocarcinoma, tumor-associated macrophages, Helicobacter pylori

Funding: the study was carried out within the framework of the Government Assignment № FZEG-2020-0060 of the Ministry of Science and Higher Education of the Russian Federation in the field of scientific research "Algorithms for molecular genetic diagnosis of malignant neoplasms and approaches to their targeted therapy using cellular and genetic technologies".

Author contribution: Golubinskaya EP — clinical data analysis, immunohistochemistry, manuscript editing; Sataieva TP, Fomochkina II - systematic analysis, manuscript writing; Kubyshkin AV — statistical analysis, manuscript editing; Makalish TP — sample preparation for morphological assessment, immunohistochemistry; Shkolyar NA — biopsy sample collection and preparation; Galyshevskaya AA, Varghese DV — morphometric data processing.

Compliance with ethical standards: the study was approved by the Ethics Committee of the Medical Academy named after S. I. Georgievsky (protocol № 15 dated December 5, 2020); the study was conducted in accordance with the Declaration of Helsinki 1964 (revised in 1975 and 1983), Good Clinical Practice (GCP) standards and the Federal Law № 323-FZ "On the Basics of Protecting the Health of Citizens in the Russian Federation" dated November 21, 2011. The informed consent was submitted by all patients.

$\square$ Correspondence should be addressed: Tatiana P. Sataieva

Bulvar Lenina, 5/7, Simferopol, 295006; tanzcool@mail.ru

Received: 19.08.2021 Accepted: 03.09.2021 Published online: 13.09.2021

DOI: $10.24075 /$ brsmu.2021.044

\section{ПРЕДИКТИВНЫЙ ПОТЕНЦИАЛ ФЕНОТИПИРОВАНИЯ МАКРОФАГАЛЬНОЙ ПОПУЛЯЦИИ В МАЛИГНИЗАЦИИ Н. РYLORI-АССОЦИИРОВАННОГО ХРОНИЧЕСКОГО ГАСТРИТА}

\author{
Е. П. Голубинская', Т. П. Сатаева' ${ }^{1}$, И. И. Фомочкина', А. В. Кубышкин1, Т. П. Макалиш', Н. А. Школяр², А. А. Галышевская', Д. В. Варгхесе ${ }^{1}$
}

${ }^{1}$ Крымский федеральный университет имени В. И. Вернадского, Симферополь, Россия

2 Первый Московский государственный медицинский университет имени И. М. Сеченова (Сеченовский Университет), Москва, Россия

Опухоль-ассоциированные макрофаги способны регулировать пролиферацию опухолевых клеток и влиять на процессы их диссеминации. Целью исследования было оценить предиктивный потенциал иммуногистохимического фенотипирования макрофагальной популяции при ранней малигнизации H. pylori-aссоциированного хронического гастрита. Материалом для исследования послужили гастробиоптаты инфицированных Helicobacter pylori пациентов обоего пола в возрасте $48 \pm$ 7,2 лет, разделенных на три группы: хронический неатросрический гастрит (ХНГ, $n=10)$, хронический атрофический гастрит (ХАГ, $n=10)$, аденокарцинома желудка G1-G2 (АКЦ, $n=10)$. Макрофрагальную популяцию визуализировали с помощью панмакрофрагального маркера CD68 и маркера моноцитов/макрофагов 2-го типа CD163. Интенсивность неоангиогенеза определяли с использованием маркера эндотелия сосудов CD31 путем оценки суммарной площади поперечного сечения сосудов. Установлено, что хронический гастрит сопровождается динамическим увеличением общей популяции макрофрагов по мере нарастания атрофических и неопластических процессов. По данным иммуногистохимического исследования биоптатов, у группы пациентов с ХНГ соотношение CD163 : CD68 составило 0,67 „ 0,02, а суммарная площадь поперечного сечения сосудов была равна 3590,92 \pm 356,27 мкм². Атрофический гастрит и аденокарцинома характеризуются векторным перераспределением моноцитов/макрофрагов во второй функциональный фенотип. Индекс экспрессии CD163 : CD68 в группе с ХАГ составляет 0,81 $\pm 0,04$, а в группе с АКЦ - 0,88 \pm 0,03. Площадь микроциркуляторного русла в группах с ХАГ и АКЦ значительно возрастает, что отражает интенсификацию процессов неоангиогенеза в опухоли под влиянием моноцитов/макрофагов M2. Усиленная экспрессия CD163 может служить предиктором малигнизации хронического гастрита в комплексе с оценкой степени атрофии и метаплазии эпителия железистого компонента.

Ключевые слова: рак желудка, гастрит, аденокарцинома, опухоль-ассоциированные макрофаги, Helicobacter pylori

Финансирование: исследование выполнено в рамках государственного задания № ФЗЭГ-2020-0060 Министерства науки и высшего образования Российской Федерации в области научных исследований по теме «Алгоритмы молекулярно-генетической диагностики злокачественных новообразований и подходы к их таргетной терапии с использованием клеточных и генетических технологий».

Вклад авторов: Е. П. Голубинская - анализ клинических данных, проведение иммуногистохимического исследования, редактирование рукописи; Т. П. Сатаева, И. И. Фомочкина - систематический анализ, написание рукописи; А. В. Кубышкин - статистический анализ полученных данных, редактирование рукописи; Т. П. Макалиш - подготовка материала для морфологического исследования, проведение иммуногистохимического исследования; Н. А. Школяр - сбор и подготовка биоптатов; А. А. Галышевская, Д. В. Варгхесе - обработка морфометрических данных.

Соблюдение этических стандартов: исследование одобрено этическим комитетом Медицинской академии имени С. И. Георгиевского (протокол №15 от 5 декабря 2020 г.), проведено в соответствии с Хельсинкской Декларацией 1964 г. (исправленной в 1975 и 1983 гг.), Стандартами надлежащей клинической практики (GCP) и ФЗ № 323-ФЗ от 21 ноября 2011 г. «Об основах охраны здоровья граждан в Российской Федерации». Все пациенты подписали добровольное информированное согласие на участие в исследовании.

$\bigotimes$ Для корреспонденции: Татьяна Павловна Сатаева

Бульвар Ленина д. 5/7, г. Симферополь, 295006; tanzcool@mail.ru

Статья получена: 19.08.2021 Статья принята к печати: 03.09.2021 Опубликована онлайн: 13.09.2021

DOI: $10.24075 /$ vrgmu.2021.044 
Currently, gastric cancer is ranked fifth for incidence and third for morbidity not just in the Russian Federation, but throughout the world. A significant increase in the number of young patients with this disorder has given rise to numerous studies aimed at identifying early predictors for carcinogenesis and critical risk factors for malignization [1, 2].

Among the gastric cancer pathogenesis factors, the Helicobacter pylori (HP) infection is the leading cause of the disorder. It's been proven that $80 \%$ of patients with gastric cancer have had a history of HP infection $[3,4]$. There is no doubt that HP is one of the crucial factors for a cascade of carcinogenesis, which initiates the development of acute gastritis, and progression from acute to chronic gastritis with subsequent atrophy, metaplasia, and dysplasia, ultimately leading to the development of adenocarcinoma [5].

In recent years, a growing body of research has been focused on the changes in the tumor microenvironment. Studying the tumor-associated macrophages (TAMs) can be very promising in the aspect of cancer research [6]. TAMs are associated with the occurrence of tumors playing a vital part in metastasis and immune regulation of neoplasms. Today, the macrophage functional heterogeneity has been established. There are type 1 macrophages, which initiate the pro-inflammatory response, and type 2 macrophages involved in remodeling, which can promote tumor cell migration and invasion due to activation of neoangiogenesis [7-9].

It is known that HP can actively recruit macrophages, monocytes and dendritic cells to the gastric mucosa. HP forces these cells to secrete pro-inflammatory cytokines and chemokines, causing inflammation and gastric mucosal injury $[10,11]$. Several studies report the influence of $H P$ infection on the macrophage polarization due to promotion of free radicals induced oxidative processes. According to the results of a number of research studies, bacterial factors contribute to the increased production of reactive oxygen species and hypoxiainducible factor $1 \alpha[8,9]$. Furthermore, HP is able to synthesize large amounts of inducible nitric oxide synthase (iNOS), contributing to macrophage polarization into M2 phenotype, which, in contrast to $M 1$, exhibit a rather low phagocytic activity, thus facilitating the further pathogen persistence [12].

Currently, endoscopy with targeted biopsies is the main method for diagnosing atrophic gastritis and its complications. However, focal lesions are quite common for HP-associated atrophic gastritis, that is why it is essential to ensure obtaining adequate biopsy samples, which is often difficult to accomplish in the outpatient setting [13]. Nevertheless, early detection of atrophy and subsequent precancerous changes (intestinal metaplasia and dysplasia) is essential for gastric cancer prevention. Immunohistochemical verification of morphological changes in gastric mucosal immune cells could be part of the solution to this problem.

In view of the above, the study was aimed to assess the predictive potential of the macrophage population immunohistochemical phenotyping in the early malignization of the HP-associated chronic gastritis.

\section{METHODS}

Morphological studies were performed in the Center for the Shared Use of Scientific Equipment "Molecular Biology" of the S.I. Georgievsky Medical Academy, V.I. Vernadsky Crimean Federal University, with support from the Crimean Federal University development program. Gastic biopsy samples of male and female patients aged $48 \pm 7.2$ infected with HP were used as the research material. The patients were divided into three groups: non-atrophic chronic gastritis $(n=10)$, atrophic chronic gastritis $(n=10), \mathrm{G} 1 / \mathrm{G} 2$ Lauren intestinal type gastric tubular adenocarcinoma $(n=10)$. Inclusion criteria: positive HP test. Exclusion criteria: negative HP test or no information about this test in medical history. According to their medical history, all patients were HP-positive. HP was verified based on the serum anti-HP immunoglobulin G (IgG) quantification by the enzyme-linked immunosorbent assay and the rapid urease test.

The control group included fragments of visually intact gastric mucosa obtained from patients, who died from causes other than gastrointestinal disorders, with no histological signs of gastritis and not infected with HP.

To perform morphological assessment of the biopsy and necropsy samples, the fragments of gastric mucosa were fixed in the $10 \%$ neutral buffered formalin. Tissue processing and histological slide preparation were performed by standard methods with subsequent hematoxylin and eosin staining [14].

Immunohistochemical staining $(\mathrm{IHC})$ was performed on the slices 3-4 $\mu \mathrm{m}$ thick by peroxidase-antiperoxidase (PAP) complex technique in accordance with the Thermo Scientific protocols (USA) with the use of Leica Biosystems visualization system (Novocastra; USA) and DAB Chromogen (Abcam; UK). Subsequently, cell nuclei were stained with hematoxylin. Macrophage population was visualized using the CD68 pan-macrophage/monocyte marker (clone PG-M1, dilution 1 : 50, DAKO; Denmark) and the CD163 marker of typical $2 \alpha$ reparative phenotype macrophages CD163 (clone EPR-19518, dilution 1 : 500, Abcam; UK). According to meta-analysis, studying the CD68 and CD163 markers is more infomative than studying the other M2 marker, CD206 [15]. Meanwhile, CD163 can be expressed as an additional surface marker of blood monocytes, which are also capable of phenotypic polarization. However, monocytes demonstrate lower expression of this marker compared to macrophages.

Intensity of neoangiogenesis was defined using the CD31 endothelial marker (clone 1A10, Leica Bond; USA) by assessing the total cross-sectional area of blood vessels.

The samples obtained were analyzed with the CX41 light microscope (Olympus; Japan). Morphometric assessment was performed using the Image $\mathrm{J}$ software $(\mathrm{NIH}$; USA) on the standardized area of the histology section image. Cells with positive cytoplasmic staining were counted in 10 fields of view using the 20x/0.50 UPlanFL N objective (Olympus; Japan) with subsequent counting the average number of cells in the biopsy sample.

Statistical analysis was carried out using the STATISTICA 10.0 software for Windows (StatSoft Inc.; USA). Testing for normal distribution was performed by the KolmogorovSmirnov test. The following statistical parameters were defined: mean $(M)$, error of the mean $(m)$. The inter-group comparisons of morphological parameters were carried out by one-way analysis of variance (One-Way ANOVA) with the use of the Dunnett test $(Q)$ for comparison of the small samples with the control group. The intra-group differences were considered significant when $p \leq 0.05$.

\section{RESULTS}

According to serological study, the antibody titer of $1: 5$ was observed in $33 \%$ of patients with NACG; in 67\% of patients the antibody titer exceeded $1: 10$. In the group with ACG, the antibody titer exceeding 1:5 was observed only in 10\% of patients; $49 \%$ of the examined patients had the antibody titer exceeding 1: 10, and another $41 \%$ of patients demonstrated 

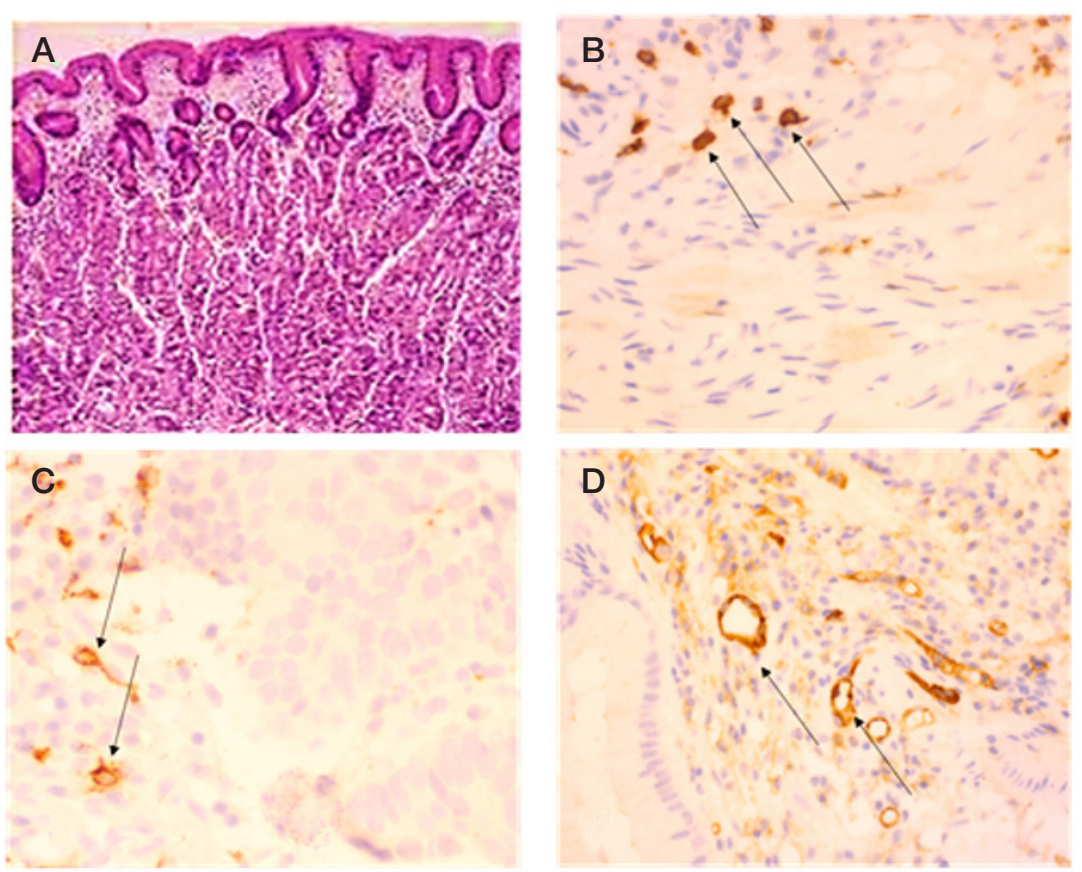

Fig. 1. Gastric mucosal pattern in controls. A. Regularly shaped columnar epithelium forming the gastric pits, hematoxylin and eosin stain ( $\times 10)$. B. CD163-positive cytoplasmic stain in solitary type 2 monocytes/macrophages, IHC (×40). C. CD68-positive cytoplasmic stain in general macrophage population, IHC ( $\times 40)$. D. CD31positive cytoplasmic stain in small vessel endothelium, $\mathrm{IHC}(\times 40)$

the high antibody titer (in the range of $1: 20-1: 80$ ). In $77 \%$ of patients with verified tubular adenocarcinoma (GAC), the antibody titer was $1: 20$ or higher, and $23 \%$ of patients had the antibody titer of $1: 5-1: 10$.

According to morphological assessment, gastric mucosa of the controls had a typical pattern, represented by the lining of regularly shaped columnar epithelium, forming the gastric pits with no signs of gastritis (Fig. 1A). In the submicosal layer, there were solitary resident macrophages of both $1^{\text {st }}$ and $2^{\text {nd }}$ phenotype (Fig. 1B, C). The moderately prominent vascular pattern was clearly visible. Blood
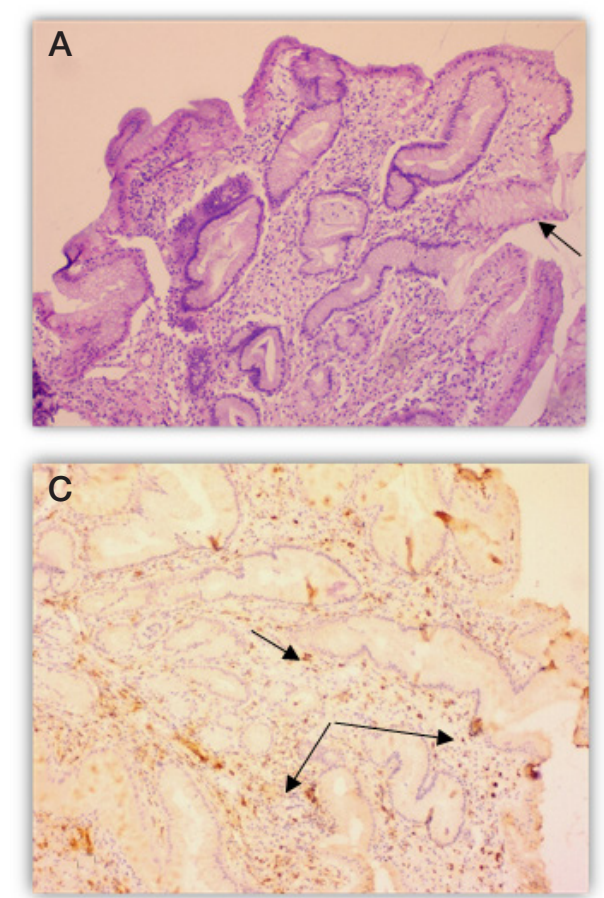

vessels were represented mainly by capillaries and venules (Fig. 1D).

When performing the overview staining, it was found that gastric biopsy specimens of patients with NCG were characterized by lymphoplasmacytic infiltration of various degree (mild to moderate), as well as by formation of solitary hyperplastic lymphoid aggregates within the stroma, increased mucoidization of the columnar epithelium of the integument and pits, and foveolar hyperplasia. In some zones of biopsy specimens there were foci of fundic gland hyperplasia (Fig. 2A).
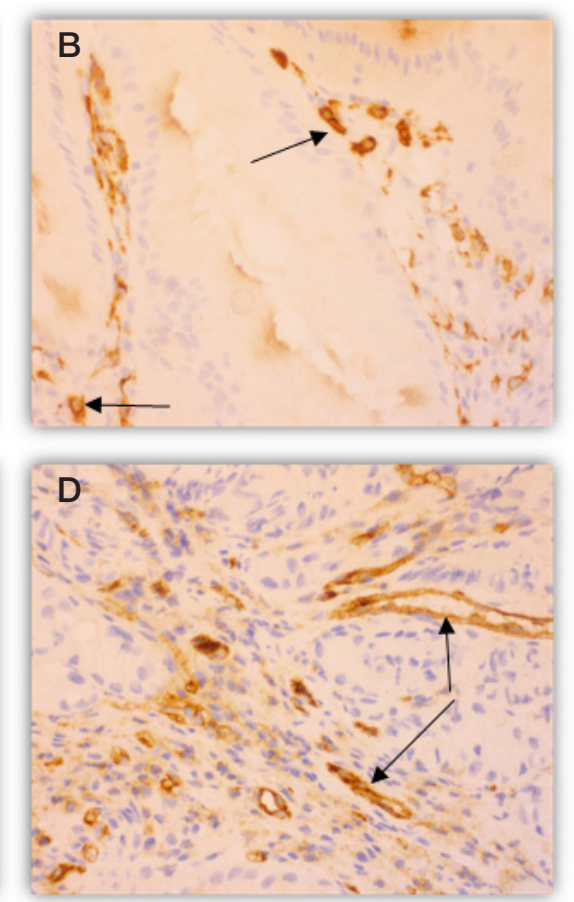

Fig. 2. Non-atrophic chronic gastritis. A. Moderate lymphoplasmacytic infiltration with admixed solitary leukocytes in the lamina propria of the antral mucosa, increased mucoidization of the columnar epithelium of the integument and pits, hematoxylin and eosin stain ( $\times 10)$. B. CD163-positive cytoplasmic stain in type 2 monocytes/ macrophages, $I H C(\times 40)$. C. CD68-positive cytoplasmic stain in general macrophage population, IHC (×10). D. CD31-positive cytoplasmic stain in blood vessel endothelium, $\mathrm{IHC}(\times 40)$ 
Table. Immunohistochemical study of macrophages and microvascular bed in patients with chronic gastritis and adenocarcinoma

\begin{tabular}{|c|c|c|c|c|}
\hline $\begin{array}{l}\mathrm{IHC} \\
\text { marker }\end{array}$ & $\begin{array}{l}\text { NACG } \\
(n=10)\end{array}$ & $\begin{array}{c}\text { ACG } \\
(n=10)\end{array}$ & $\begin{array}{l}\text { GAC } \\
(n=10)\end{array}$ & $\begin{array}{l}\text { Control group } \\
\quad(n=10)\end{array}$ \\
\hline $\begin{array}{c}\mathrm{CD} 68 \\
\text { Abs., }(\mathrm{M} \pm m)\end{array}$ & $\begin{array}{c}39.9 \pm 3.12^{*} \\
\mathrm{Q}=5.90 \\
(p=0.00243)\end{array}$ & $\begin{array}{c}62.7 \pm 3.39^{\star} \\
Q=21.59 \\
(p=0.00000)\end{array}$ & $\begin{array}{c}132.4 \pm 6.71^{\star} \\
Q=68.99 \\
(p=0.00000)\end{array}$ & $31.1 \pm 4.71$ \\
\hline $\begin{array}{c}\text { CD } 163 \\
\text { Abs., }(M \pm m)\end{array}$ & $\begin{array}{c}27.5 \pm 2.83^{*} \\
\mathrm{Q}=8.69 \\
(p=0.00003)\end{array}$ & $\begin{array}{c}50.5 \pm 3.54^{*} \\
\mathrm{Q}=24.17 \\
(p=0.00000)\end{array}$ & $\begin{array}{c}116.7 \pm 10.14^{*} \\
\mathrm{Q}=68.47 \\
(p=0.00000)\end{array}$ & $14.7 \pm 3.15$ \\
\hline $\begin{array}{c}\mathrm{CD} 31 \\
\mu m^{2},(\mathrm{M} \pm m)\end{array}$ & $\begin{array}{c}3590.92 \pm 356.27 \\
\mathrm{Q}=2.07 \\
(p=0.48170)\end{array}$ & $\begin{array}{c}8647.02 \pm 359.29^{*} \\
Q=27.95 \\
(p=0.00000)\end{array}$ & $\begin{array}{c}19065.12 \pm 1042.94^{*} \\
\mathrm{Q}=82.37 \\
(p=0.00000)\end{array}$ & $3203.68 \pm 347.21$ \\
\hline CD163 : CD68 & $\begin{array}{c}0.67 \pm 0.02^{*} \\
\mathrm{Q}=13.97 \\
(p=0.00000)\end{array}$ & $\begin{array}{c}0.81 \pm 0.04^{\star} \\
\mathrm{Q}=23.75 \\
(p=0.00000)\end{array}$ & $\begin{array}{c}0.88 \pm 0.03^{*} \\
\mathrm{Q}=28.64 \\
(p=0.00000)\end{array}$ & $0.47 \pm 0.07$ \\
\hline
\end{tabular}

Note: * - significant differences with the control group, $p \leq 0.05$

According to $\mathrm{IHC}$ study of biopsies obtained from patients with NACG, CD68 ${ }^{+}$cells were distributed homogeneously in the lamina propria of the gastric mucosa; type 2 monocytes/ macrophages made up about a half of these cells. The CD163 : CD68 ratio of $0.67 \pm 0.02$ (Fig. 2B, C) was significantly larger compared to values obtained for the control group ( $p<0.05)$. In our view, the monocyte/macrophage population ratio index shift compared to the control group is indicative of the proinflammatory response cascade initiation.

The total cross-sectional area of blood vessels in patients with NACG was $3590.92 \pm 356.27 \mu m^{2}$, which was indicative of insignificant intensification of angiogenesis compared with the control group specimens $(p>0.05)$. The cross-sectional area of blood vessels in patients with this type of gastritis was minimal in comparison with the groups of patients with ACG and GAC (Fig. 2D; Table).

Biopsies of patients with ACG also demonstrated polymorphic histological changes. Glandular atrophy resulted from two fundamentally different processes: fibrous stroma transformation or intestinal metaplasia (small/large intestine or the combination of these metaplasia types). Atrophic gastritis with the lamina propria fibrosis was characterized by the marked lymphoplasmacytic infiltration, often with lymphoid follicles consisting of expanded germinal centers (Fig. 3A).

The monocyte/macrophage population was also distributed homogeneously throughout the whole biopsy specimens, both in foveolar zones and in the vicinity of the lymphoid accumulation. The majority of cells had the type 2 monocyte/ macrophage immunophenotype. The CD163 : CD68 ratio was $0.81 \pm 0.04$ (Fig. 3B, C). Furthermore, microvascular area in biopsies of this subgroup was significantly increased compared to values obtained both for NACG group and control group (Fig. 3D).

Morphological and immunohistochemical changes in biopsies of patients with verified tubular adenocarcinoma were particularly illustrative in terms of the macrophage population functional re-profiling and the intensity of neoangiogenesis. Among tubular structures with signs of cellular and nuclear atypia, and areas of solid structure, the desmoplastic stroma with moderate and marked dense inflammatory cell infiltrate of lymphoid cells, histiocytes, neutrophils were observed (Fig. 4A).
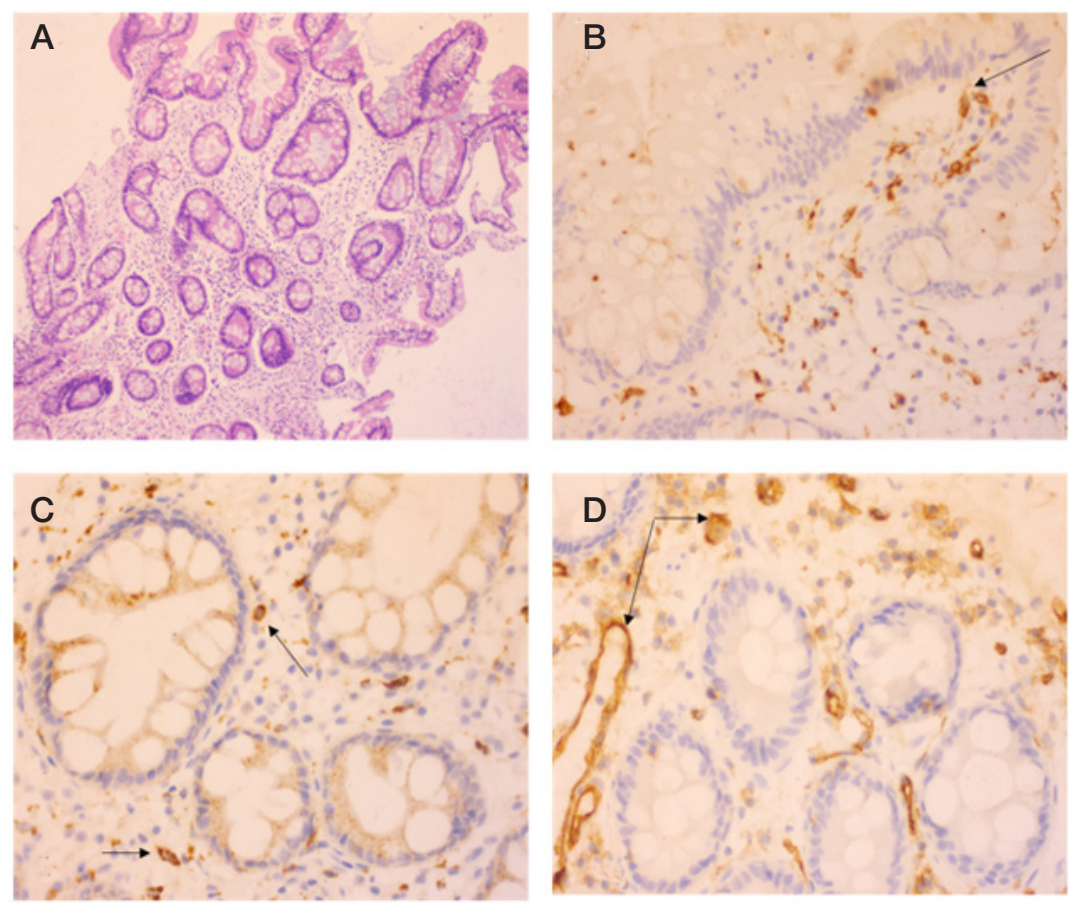

Fig. 3. Moderate subactive metaplastic atrophic chronic gastritis. A. Large intestinal metaplasia, hematoxylin and eosin stain ( $\times 10)$. B. CD163-positive cytoplasmic stain in type 2 monocytes/macrophages within lamina propria mucosae, IHC $(\times 40)$. C. CD68-positive cytoplasmic stain in macrophages within lamina propria mucosae, IHC (×40). D. CD31-positive cytoplasmic stain in blood vessel endothelium, IHC (×40) 

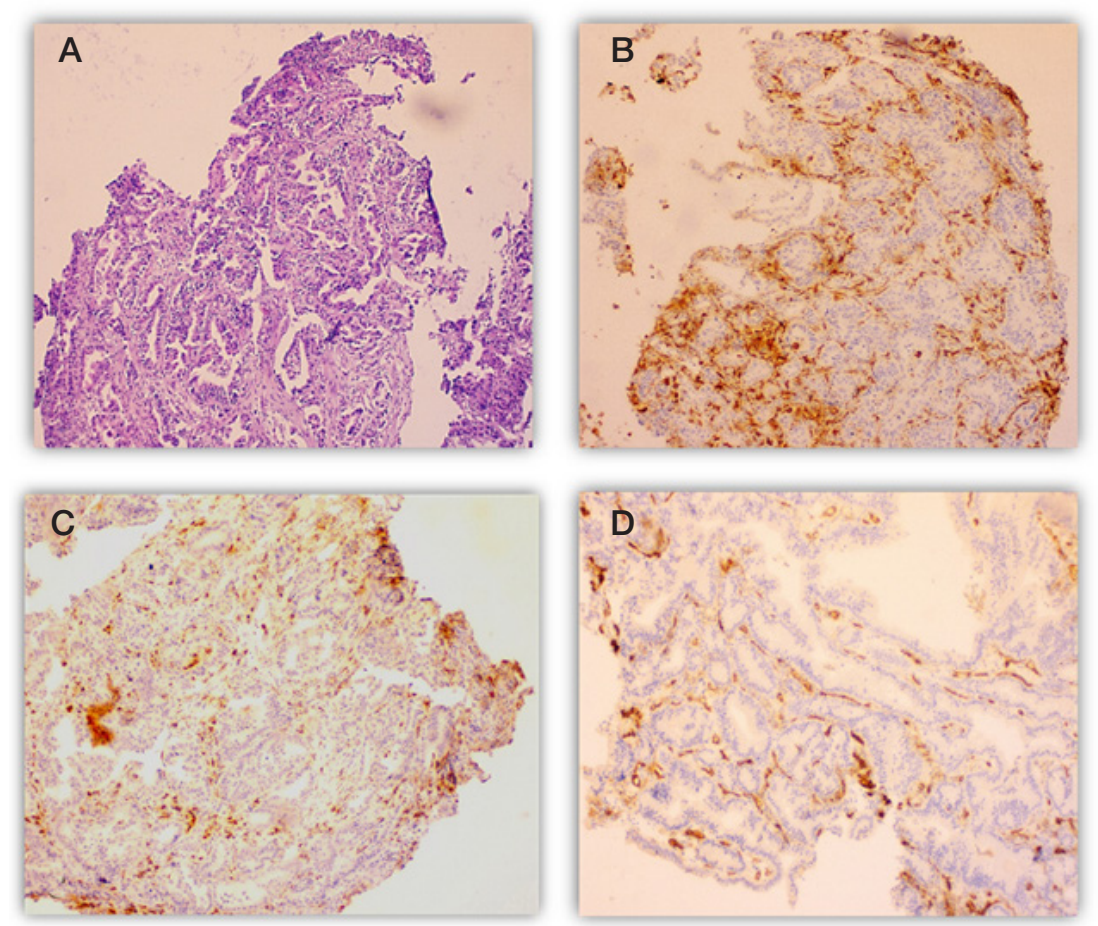

Fig. 4. Adenocarcinomas. A. Tubular adenocarcinoma with ulceration, hematoxylin and eosin stain ( $\times 10)$. B. CD163-positive cytoplasmic stain, IHC ( $\times 100)$. C. CD68positive cytoplasmic stain, $I H C(\times 100)$. D. CD31-positive cytoplasmic stain, $I H C(\times 200)$

The number of cells in monocyte/macrophage population increased twice compared to values obtained for ACG and four times compared to value obtained for NACG. The CD163 : CD68 expression ratio was $0.88 \pm 0.03$ (Fig. 4B, C). The maximum microvascular area, significantly exceeding the control values, was also observed (Fig. 4D), which could be indicative of the intensified neoangiogenesis aimed at forming the comfortable microenvironment, and contributed to metastatic tumor cell dissemination [16].

\section{DISCUSSION}

The known molecular biomarkers of monocytes/macrophages demonstrate the considerable diagnostic capacity and could serve as malignancy risk predictors due to specific identification of particular immune cell subpopulations, allowing one to predict the course of a number of disorders. There is evidence that macrophages can play a dual role in inflammation depending on the signals from their microenvironment due to different phenotypes [17].

Chronic HP-associated gastritis is accompanied by the dynamic increase in the size of the general monocyte/ macrophage population, since it is known that HP actively triggers the cytokine cascade playing a vital part in realization of chronic inflammatory and destructive processes in the gastric mucosa [4]. During the acute inflammatory response, macrophages are usually polarized into M1 phenotype by interferon- $\gamma$ and microbial products, such as lipopolysaccharide, and exhibit strong antimocrobial activity due to production of bactericidal components (nitric oxide and oxygen radicals) [9]. However, this bacterium can inhibit the effects of active substances produced by macrophages due to neutralizstion of these substances with catalase and superoxide dismutase, which provides survival of the bacteria. However, the reactive oxygen species, abundantly secreted by macrophages, cause the death of the gastric mucosal cells, which contributes to the risk of atrophy [18].

According to our study, atrophic gastritis is characterized by vector redistribution of monocytes/macrophages into the 2nd functional type. M2 macrophages are induced by type 2 T-helper cells or anti-inflammatory cytokines and growth factors, including IL4, IL10 [6]. Apparently, monocyte/ macrophage polarization shift towards M2 with the progression of inflammation should ensure tissue regeneration and enhance humoral response. However, the long-term increased production of the HP pathogenicity factors may lower the ability of macrophages to eliminate bacterial antigens, which results in the long-term persistence of the pathogen and chronic inflammation $[19,20]$. At the same time, chronic inflammation with persistent M2 monocyte/macrophage polarization is associated with increased risk of developing gastric cancer $[1,13,21]$.

Thus, the dynamic increase in the pan-macrophage population size and progressive re-profiling of macrophages into the $2^{\text {nd }}$ functional phenotype with the transition from non-atrophic gastritis to atrophic gastritis, and peak values in biopsies with gastric adenocarcinoma, were observed during our study. In our opinion, these changes are related to remodeling functional activity of the alternatively activated M2 monocytes/macrophages due to increased expression of proangiogenic growth factors, which on the one hand contributes to fibrotic changes in the gastric stroma in the conditions of chronic progressive inflammation and tissue hypoxia, and on the other hand creates a comfortable microenvironment for the dysplastic and neoplastic changes in the glandular epithelium [11, 22]. Furthermore, it is well-known that certain M2 macrophage populations exhibit the vivid tumor-stimulating activity, since these populations are involved in the local immunosuppression of immunocompetent cells, which results in the tumor cell escape from the immune surveillance [23].

The diversity of monocyte/macrophage phenotypes requires further study and standardization of their predictive potential. For this purpose, the studies of the larger number of patient samples should be carried out, as well as the assessment of the other macrophage markers, typical for monocytes and macrophages. In particular, monocytes are able to express the CD163 and CD204 surface markers in 
addition to the CD1 and CD16 surface markers, which could be defined by double staining immunohistochemistry [24]. Furthermore, regardless of the generally accepted division of macrophages into classical and alternative macrophages, the other macrophage subtypes have been described, including the pro-fibrotic M2-like macrophages, which produce growth factors, and ischemia-induced fibrolytic M2-like macrophages, which secrete proteases [12].

In general, identification of the TAM functional programming mechanisms would make it possible to identify terapeutic targets, and to develop new approaches to treatment of cancer patients based on the combination of chemotherapy and immunomodulatory agents in order to induce the immune response to the tumor [13]. Synergistic effects of these modalities may significantly increase the efficiency of antitumor therapy.

\section{CONCLUSIONS}

Chronic $H$. pylori-associated gastritis is accompanied by the dynamic increase in the size of the general macrophage population with the progression of atrophic and metaplastic processes. Atrophic gastritis and adenocarcinoma are characterized by vector redistribution of macrophages into the 2nd functional type. Increased expression of CD163 marker of monocytes/macrophages can serve as a predictor of chronic gastritis malignancy together with histological study of the glandular epithelium atrophy and metaplasia degree.

\section{References}

1. Jemal A, Bray F, Center MM, Ferlay J, Ward E, Forman D. Global cancer statistics. CA Cancer J Clin. 2011; 61 (2): 69-90.

2. Massarrat S, Stolte M. Development of gastric cancer and its prevention. Arch Iran Med. 2014; 17 (7): 514-20.

3. Cover TL. Helicobacter pylori diversity and gastric cancer risk. MBio. 2016; 7: e01869-915.

4. Mentis AA, Dardiotis E. Helicobacter pylori eradication for metachronous gastric cancer: an unsuitable methodology impeding broader clinical usage. Front Oncol. 2019 Feb 20; 9: 90. DOI: 10.3389/fonc.2019.00090.

5. Mentis AA, Boziki M, Grigoriadis N, Papavassiliou AG. Helicobacter pylori infection and gastric cancer biology: tempering a doubleedged sword. Cell Mol Life Sci. 2019; 76: 2477-86.

6. Biswas SK, Mantovani A. Macrophage plasticity and interaction with lymphocyte subsets: cancer as a paradigm. Nat Immunol. 2010; 11: 889.

7. Kim J, Bae J-S. Tumor-associated macrophages and neutrophils in tumor microenvironment. Mediators Inflamm. 2016; 6058147.

8. Niu Z, Shi Q, Zhang W, et al. Caspase-1 cleaves PPAR (for potentiating the pro-tumor action of TAMs. Nat Commun. 2017; 8: 766

9. Lu Y, Rong J, Lai Y, Tao L, Yuan X, Shu X. The degree of Helicobacter pylori infection affects the state of macrophage polarization through crosstalk between ROS and HIF-1 $\alpha$. Oxid Med Cell Longev. 2020; 2020: 5281795.

10. Quiding-Järbrink $M$, Raghavan $S$, Sundquist $M$. Enhanced $M 1$ macrophage polarization in human Helicobacter pylori-associated atrophic gastritis and in vaccinated mice. PLoS One. 2010; 5 (11): p.e15018. DOI: 10.1371/journal.pone.0015018.

11. Li W, Zhang X, Wu F, et al. Gastric cancer-derived mesenchymal stromal cells trigger M2 macrophage polarization that promotes metastasis and Emt in gastric cancer. Cell Death \& Disease. 2019; 10 (12): 918. DOI: 10.1038/s41419-019-2131-y.

12. Atri C, Guerfali FZ, Laouini D. Role of human macrophage polarization in inflammation during infectious diseases. Int $\mathrm{J} \mathrm{Mol}$ Sci. 2018; 19 (6): 1801. DOI: 10.3390/jms19061801.

13. Song JH, Kim SG, Jin EH, Lim JH, Yang SY. Risk factors for gastric tumorogenesis in underlying gastric mucosal atrophy. Gut Liver. 2017; 11: 612-19.

\section{Литература}

1. Jemal A, Bray F, Center MM, Ferlay J, Ward E, Forman D. Globa cancer statistics. CA Cancer J Clin. 2011; 61 (2): 69-90.

2. Massarrat S, Stolte M. Development of gastric cancer and its prevention. Arch Iran Med. 2014; 17 (7): 514-20.

3. Cover TL. Helicobacter pylori diversity and gastric cancer risk. MBio. 2016; 7: e01869-915.

4. Mentis AA, Dardiotis E. Helicobacter pylori eradication for metachronous gastric cancer: an unsuitable methodology impeding broader clinical usage. Front Oncol. 2019 Feb 20; 9:
14. Janin VL, Bondarenko OM, Sazonova NA. Metody issledovanija v citologii i gistologii. Hanty-Mansijsk: BU "Hanty-Mansijskaja gosudarstvennaja medicinskaja akademija", 2015; 65 s. Russian.

15. Ni C, Yang L, Xu Q, Yuan H, et al. CD68- and CD163-positive tumor infiltrating macrophages in non-metastatic breast cancer: a retrospective study and meta-analysis. J Cancer. 2019 Jul 23; 10 (19): 4463-72. DOI: 10.7150/jca.33914.

16. Kloepper J, et al. Ang-2NEGF bispecific antibody reprograms macrophages and resident microglia to anti-tumor phenotype and prolongs glioblastoma survival. Proc Natl Acad Sci USA. 2016; 113: 4476-81.

17. Murray PJ. Macrophage Polarization. Annu Rev Physiol. 2017; 79 (1): 541-66. DOI: 10.1146/annurev-physiol-022516-034339.

18. Wang YH, LV ZF, Zhong Y, Liu DS, Chen SP, Xie Y. The internalization of Helicobacter pylori plays a role in the failure of $H$. pylori eradication. Helicobacter. 2017; 22 (1). DOI: 10.1111/hel.12324.

19. Ihrig M, Whary MT, Dangler CA, Fox JG. Gastric helicobacter infection induces a Th2 phenotype but does not elevate serum cholesterol in mice lacking inducible nitric oxide synthase. Infect Immun. 2005; 73: 1664-70.

20. Kaparakis M, Walduck AK, Price JD, Pedersen JS, van Rooijen N, et al. Macrophages are mediators of gastritis in acute Helicobacter pylori infection in C57BL/6 mice. Infect Immun. 2008; 76: 2235-9.

21. Liu LP, Sheng XP, Shuai TK, Zhao YX, Li B, Li YM. Helicobacter pylori promotes invasion and metastasis of gastric cancer by enhancing heparanase expression. World J Gastroenterol. 2018; 24 (40): 4565-77. DOI: 10.3748/wjg.v24.i40.4565

22. Binnemars-Postma $K$, Bansal R, Storm G, et al. Targeting the Stat6 pathway in tumor-associated macrophages reduces tumor growth and metastatic niche formation in breast cancer. FASEB J. 2017; 32: 969-78.

23. Cortese N, Donadon M, Rigamonti A, Marchesi F. Macrophages at the crossroads of anticancer strategies. Front Biosci (Landmark Ed). 2019 Jun 1; 24: 1271-83.

24. Kzhyshkowska J, Gudima A, Moganti K, Gratchev A, Orekhov A Perspectives for monocyte/macrophage-based diagnostics of chronic inflammation. Transfus Med Hemother. 2016; 43 (2): 66-77. DOI: 10.1159/000444943.

90. DOI: 10.3389/fonc.2019.00090

5. Mentis AA, Boziki M, Grigoriadis N, Papavassiliou AG. Helicobacter pylori infection and gastric cancer biology: tempering a doubleedged sword. Cell Mol Life Sci. 2019; 76: 2477-86.

6. Biswas SK, Mantovani A. Macrophage plasticity and interaction with lymphocyte subsets: cancer as a paradigm. Nat Immunol. 2010; 11: 889 .

7. Kim J, Bae J-S. Tumor-associated macrophages and neutrophils in tumor microenvironment. Mediators Inflamm. 2016; 6058147. 
8. Niu Z, Shi Q, Zhang W, et al. Caspase-1 cleaves PPAR (for potentiating the pro-tumor action of TAMs. Nat Commun. 2017; 8: 766.

9. Lu Y, Rong J, Lai Y, Tao L, Yuan X, Shu X. The degree of Helicobacter pylori infection affects the state of macrophage polarization through crosstalk between ROS and HIF-1 $\alpha$. Oxid Med Cell Longev. 2020; 2020: 5281795.

10. Quiding-Järbrink $M$, Raghavan $S$, Sundquist $M$. Enhanced $M 1$ macrophage polarization in human Helicobacter pylori-associated atrophic gastritis and in vaccinated mice. PLoS One. 2010; 5 (11): p.e15018. DOI: 10.1371/journal.pone.0015018.

11. Li W, Zhang X, Wu F, et al. Gastric cancer-derived mesenchymal stromal cells trigger M2 macrophage polarization that promotes metastasis and Emt in gastric cancer. Cell Death \& Disease. 2019; 10 (12): 918. DOI: 10.1038/s41419-019-2131-y.

12. Atri C, Guerfali FZ, Laouini D. Role of human macrophage polarization in inflammation during infectious diseases. Int $\mathrm{J} \mathrm{Mol}$ Sci. 2018; 19 (6): 1801. DOI: 10.3390/ijms19061801.

13. Song JH, Kim SG, Jin EH, Lim JH, Yang SY. Risk factors for gastric tumorogenesis in underlying gastric mucosal atrophy. Gut Liver. 2017; 11: 612-19.

14. Янин В. Л., Бондаренко О. М., Сазонова Н. А. Методы исследования в цитологии и гистологии. Ханты-Мансийск: БУ «Ханты-Мансийская государственная медицинская академия", 2015; 65 c.

15. Ni C, Yang L, Xu Q, Yuan H, et al. CD68- and CD163-positive tumor infiltrating macrophages in non-metastatic breast cancer: a retrospective study and meta-analysis. J Cancer. 2019 Jul 23; 10 (19): 4463-72. DOI: 10.7150/jca.33914.

16. Kloepper J, et al. Ang-2NEGF bispecific antibody reprograms macrophages and resident microglia to anti-tumor phenotype and prolongs glioblastoma survival. Proc Natl Acad Sci USA. 2016; 113: 4476-81.

17. Murray PJ. Macrophage Polarization. Annu Rev Physiol. 2017; 79 (1): 541-66. DOI: 10.1146/annurev-physiol-022516-034339.

18. Wang YH, Lv ZF, Zhong Y, Liu DS, Chen SP, Xie Y. The internalization of Helicobacter pylori plays a role in the failure of $H$. pylori eradication. Helicobacter. 2017; 22 (1). DOl: 10.1111/hel.12324.

19. Ihrig M, Whary MT, Dangler CA, Fox JG. Gastric helicobacter infection induces a Th2 phenotype but does not elevate serum cholesterol in mice lacking inducible nitric oxide synthase. Infect Immun. 2005; 73: 1664-70.

20. Kaparakis M, Walduck AK, Price JD, Pedersen JS, van Rooijen N, et al. Macrophages are mediators of gastritis in acute Helicobacter pylori infection in C57BL/6 mice. Infect Immun. 2008; 76: 2235-9.

21. Liu LP, Sheng XP, Shuai TK, Zhao YX, Li B, Li YM. Helicobacter pylori promotes invasion and metastasis of gastric cancer by enhancing heparanase expression. World J Gastroenterol. 2018; 24 (40): 4565-77. DOI: 10.3748/wjg.v24.i40.4565.

22. Binnemars-Postma K, Bansal R, Storm G, et al. Targeting the Stat6 pathway in tumor-associated macrophages reduces tumor growth and metastatic niche formation in breast cancer. FASEB J. 2017; 32: 969-78.

23. Cortese N, Donadon M, Rigamonti A, Marchesi F. Macrophages at the crossroads of anticancer strategies. Front Biosci (Landmark Ed). 2019 Jun 1; 24: 1271-83.

24. Kzhyshkowska J, Gudima A, Moganti K, Gratchev A, Orekhov A. Perspectives for monocyte/macrophage-based diagnostics of chronic inflammation. Transfus Med Hemother. 2016; 43 (2): 66-77. DOI: 10.1159/000444943. 